Schlenk, F. and Snell, E. E. (1945). J. biol. Chem. 157, 425.

Scott, M. L., Norris, L. C., Heuser, G. F. and Bruce, W. F. (1945). J. biol. Chem. $158,291$.

Seott, M. L., Norris, L. C., Heuser, G. F., Bruce, W. F., Coover, H. W., Bellamy, W. D. and Gunsalus, I. C. (1944). J. biol. Chem. 154, 713.

Simmons, R. W. and Norris, E. R. (1941). J. biol. Chem. 140, 679.

Smith, F. R. (1943). J. Bact. 46, 369 .

Snell, E. E. and Rannefeld, A. N. (1945). J. biol. Chem. 157, 475.

Sprince, H. and Woolley, D. W. (1944). J.exp. Med. 80, 213.

Stiller, E. T., Harris, S. A., Finkelstein, J., Keresztesy, J. C. and Folkers, K. (1940). J. Amer. chem. Soc. 62, 1785.

Stiller, F. T., Keresztesy, J, C. and Stevens, J. R. (1939). J. Amer, chem. Soe. 61, 1237.

Stokes, J. L. $(1944$, I). J. Bact. 47, 433.

Stokes, J. L. (1944, 2). J. Bact. 48, 201.

Stokes, J. L., Koresztesy, J. C. and Foster, J. W. (1944). Science, 100, 522.

Stokstad, E. L. R. (1943). J. biol. Chem. 149, 573.

Subbarow, Y. and Hitchings, G. H. (1939). J. Amer. chem. Soc. 61, 1615.

Sydenstricker, V. P., Singal, S. A., Briggs, A. P., de Vaughn, N. M. and Isbell, H. (1942, 1). Science, 95, 176.

Sydenstricker, V. P., Singal, S. A., Briggs, A. P., de Vaughn, N. M. and Isbell, H. $(1942,2)$. J. Amer. med. Ass. 118, 1199.

Totter, J. R. and Day, P. L. (1943). J. biol. Chem. 147, 257.

Totter, J. R., Mims, V. and Day, P. L. (1944). Science, 100, 223.

Totter, J. R., Shukers, C. F., Kolson, J., Mims, V. and Day, P. L. (1943). Fed. Proc. 2, 72.

Totter, J. R., Shukers, C. F., Kolson, J., Mims, V. and Day, P. L. (1944). J. biol. Chem. 152, 147 .

Tschesche, R. and Wolf, H. J. (1937). Hoppe-Seyl. Z. 248, 34.

Waisman, H. A., McCall, K. B. and Elvehjem, C. A. (1945). J. Nutrit. 29, 1.

Wildiers, E. (1901). Cellule, 18, 313.

Williams, R. R. and Waterman, R. E. (1928). J. biol. Chem. 78, 311 .

Woolley, D. W. and Sprince, H. (1944). J. biol. Chem. 153, 687.

Wright, L. D. and Skeggs, H. R. (1944). Proc. Soc. exp. Biol., N.Y., 55, 92.

Wright, L. D., Skeggs, H. R. and Welch, A. D. (1944). Fed. Proc. 3, 88.

Wright, L. D. and Welch, A. D. (1.844). J. Nutrit. 27, 55.

\title{
Growth Factors and Growth Inhibitors for Micro-organisms
}

\author{
Dr. B. C. J. G. Knight (The Wellcome Physiological Research Laboratories, \\ Beckenham, Kent)
}

\section{Essential Metabolites}

We have had from Drs. Harris and Kodicek (1946) a survey of the substances of the vitamin $B$ complex considered from the point of view of their nutritional significance in higher animals, and from Dr. Quastel (1946) an account of those which are known as components of enzyme systems. These are two of the lines of investigation which have led to the chemical characterization of some of those substances which are now seen to contribute to fundamental metabolic processes common to the widest variety of cells. Of course, the observation of the wide distribution in nature of similar enzymic reactions already provided a basis for a belief in the fundamental unity of all biochemistry which Kluyver, for example, has always stressed, and which is implicit in our conception of the evolution of living organisms.

Originally the nutrient requirements of yeasts and bacteria also were independent fields of study, but these likewise have converged in the 
study of the fundamental processes of cell metabolism. This was emphasized when it was found that certain vitamins already known in animal nutrition (aneurin and riboflavin), and parts of the prosthetio groups of certain enzyme systems (pyridine-nucleotides and riboflavin), were growth factors for certain micro-organisms.

The study of the nutrient requirements of micro-organisms has now yielded a knowledge of other substances which are important also in the nutrition of widely different organisms, extending from yeasts, bacteria, the lower fungi, and the protozoa, to the higher animals. Table 1 shows

\section{TABLE 1}

Growth Factors for Micro-organisms: their Ritation to the Nutrition of other Organisms, and their funotion in Enzyme Systems

\begin{tabular}{|c|c|c|c|}
\hline Substance & $\begin{array}{c}\text { Species for which } \\
\text { the substance was } \\
\text { first recognized } \\
\text { as an essential } \\
\text { nutrient }\end{array}$ & $\begin{array}{c}\text { Species in whose } \\
\text { nutrition it was } \\
\text { subsequently found } \\
\text { to be implicated }\end{array}$ & $\begin{array}{l}\text { Enzymes or } \\
\text { substances of } \\
\text { which it is a } \\
\text { component }\end{array}$ \\
\hline $\begin{array}{l}\text { Aneurin (vitamin } \\
\mathbf{B}_{1} \text { ) }\end{array}$ & Higher animals & $\begin{array}{l}\text { Bacteria, lower } \\
\text { fungi, protozoa, } \\
\text { roots of higher } \\
\text { plants }\end{array}$ & $\begin{array}{l}\text { Co-carboxylase, } \\
\text { aneurin-protein } \\
\text { enzymes }\end{array}$ \\
\hline $\begin{array}{l}\text { Riboflavin (vitamin } \\
\mathrm{B}_{2} \text { ) }\end{array}$ & Higher animals & $\begin{array}{l}\text { Bacteria, insects, } \\
\text { lower fungi }\end{array}$ & $\begin{array}{l}\text { Several flavoprotein } \\
\text { enzymes }\end{array}$ \\
\hline $\begin{array}{l}\text { Pyridoxin (vitamin } \\
\mathrm{B}_{8} \text { ) }\end{array}$ & Higher animals & $\begin{array}{l}\text { Bacteria, insects, } \\
\text { lower fungi, plant } \\
\text { roots }\end{array}$ & $\begin{array}{l}\text { Co-enzyme of tyro- } \\
\text { sine decarboxy- } \\
\text { lase }\end{array}$ \\
\hline Pyridine nucleotides & $\begin{array}{c}\text { Haemophilus } \\
\text { influenzae }\end{array}$ & & - \\
\hline Nicotinic acid & Staph. aureus & $\begin{array}{l}\text { Higher animals, in- } \\
\text { sects, plant roots }\end{array}$ & $\begin{array}{l}\text { Co-enzymes I and } \\
\text { II, pyridine-pro- } \\
\text { tein enzymes }\end{array}$ \\
\hline Biotin & Yeasts & $\begin{array}{l}\text { Bacteria, higher } \\
\text { animals, insects, } \\
\text { lower fungi }\end{array}$ & 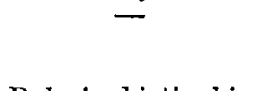 \\
\hline Pimelic acid & C. diphtheriae & - & $\begin{array}{l}\text { Role in biotin bio. } \\
\text { synthesis }\end{array}$ \\
\hline Pantothenic acid & Yeasts & $\begin{array}{l}\text { Bacteria, higher } \\
\text { animals, insects }\end{array}$ & \\
\hline$\beta$-Alanine & Yeasts & C. diphtheriae & Pantothenic acid \\
\hline $\begin{array}{l}p \text {-Aminobenzoic } \\
\text { acid }\end{array}$ & Bacteria & $\begin{array}{l}\text { Higher animals, } \\
\text { lower fungi }\end{array}$ & - \\
\hline Inositol & Yoasts & $\begin{array}{c}\text { Mice, insocts, mould } \\
(\text { Ashbya gossypi })\end{array}$ & $\longrightarrow$ \\
\hline Uracil & $\begin{array}{l}\text { Staph, aureus } \\
\text { (anaerobic) }\end{array}$ & 一 & 一 \\
\hline Glutamine & Streptococci & 一 & - \\
\hline
\end{tabular}

a list of some of the substances which have been identified as growth factors for one or more species of micro-organism, and their relation, where known, to other organisms and to enzyme systems. It will be noted that some of these substances, $\beta$-alanine, nicotinic acid, and possibly pimelic acid, form parts of the structures of more complex substances in the same list. It is now almost a commonplace that a vox. 4, 1946] 
substance which is found to be a growth factor for one species of organism may be important in the nutrition of quite different species. Complementary to this kind of observation is the very general finding that, when an organism does not need one of these substances as a nutrient, it is usually capable of synthesizing it.

There is an interesting case which is an apparent exception to this generalization, in the replacement of folic acid by thymine in the nutrition of Streptococcus lactis R (Stokes, 1944). 'This action of thymine was found to be very specific; many other purines and pyrimidines were ineffective, but the amount of thymine required was at least 5000 times that of folic acid. With this quantity of thymine used for growth, no folic acid could be detected. The largo quantity of thymine required as substitute for folic acid was enough, if it served directly as a building. stone, to account for the bacterial nucleic acid synthesized. Stokes suggested that the normal function of folic acid within the organism was in an enzyme system responsible for the synthesis of thymine, or a derivative of it, which was used by the organism to form its nucleic acid, but that, in the presence of sufficient preformed thymine, folic acid was no longer necessary for growth, the synthesis of thymine becoming superfluous in the presence of a sufficient extraneous supply; the need for folic acid as a growth factor was thus obviated by supplying enough of the product of the synthesis in which folic acid was assumed to function. This example is introduced here to emphasize the need to consider the metabolic processes of the cell as a whole. Alterations in the supply of a growth factor may have wide repercussions on the metabolism of the cell, and may involve considerations of metabolic adaptability and of the provision of alternative metabolic pathways, problems, that is, of the biological flexibility of the cell.

With considerations of this kind as a limitation, it may in general be said that the substances which have been discovered to be growth factors supplying nutritional needs are recognized as such because the cells cannot synthesize certain components of their essential metabolic reaction systems, and not because those cells have unusual metabolic processes for which they require special substances not used by other organisms.

A good case can be put forward, much ovidence coning from comparative studies with micro-organisms, that there are certain fundamental metabolic processes which are common to, and essential for, the life of all cells, and that differences in the nutritional requircments of organisms reflect their differing abilities to synthesize the components in these fundamental processes of cell metabolism. Thus, ancurin, riboflavin, the pyridine nucleotides and pyridoxin are all known as components of enzyme systems of the widest distribution, but different organisms acquire these substances, needed for metabolic reactions which they all use, in different ways, either by more or less extensive synthesis, or, complementarily, by taking the substances, preformed to a greater or less extent, from the nutrient environment. Thus it is the metabolic reactions in which these substances take part which are cardinal, while the ways in which different organisms acquire the means to carry out these common reactions of cell metabolism vary according to the ability of particular organisms to synthesize these substances. Fildes (1940) has called these substances essential metabolites. Here the word metabolite is used in 
the wide sense of a participant, as substrate, as part of an enzyme system, as structural material, or in some other role, in the essential metabolic processes of cells. An essential metabolite becomes of nutritional importance when it is not synthesized, or is not synthesized rapidly enough, by a given organism; it is then recognizable as a growth factor, growth stimulant, vitamin, or nutrilite, depending on the observed effects produced by a deficiency of it.

The material which organisms take from their nutrients is used to build up new, functioning cells. The cell carries out a complex interwoven series of reactions, which is the life of the cell, and which consists in taking compounds from the environment and using them, or synthesizing others from them, to make new functioning cells or to replace what has been worn away. The fundamental metabolic processes then in part consist of the biological mechanisms which build up the working parts of the cell, that is, the enzyme systems which build enzymes and those which lead to the supply of energy required for these synthetic processes.

While much is known about the intermediate stages of carbohydrate metabolism by means of which organisms of so many different kinds obtain the energy needed for the synthesis of their living substance, much less is known about the ways in which the enzyme systems responsible for the carbohydrate metabolism are themselves synthesized. It is hore, however, that it seems possible that studies of essential metabolites by means of micro-organisms may prove illuminating. There are cases where partial structures of growth factors recognized for certain species can act as sufficient growth factors for other species. For example, micro-organisms are known which, respectively, can build up the pyridinenucleotide co-enzymes I and II from ammonia, nicotinic acid, nicotinamide or nicotinamide riboside. There are similar series able to use $\beta$-alanine, pantoic acid and pantothenic acid, and again, pimelic acid, the diamino-carboxylic acid derived from biotin by opening the urea ring, and biotin. Such series may be indications of the routes of biosynthesis of the corresponding essential metabolites, co-enzymes I and II, pantothenic acid and biotin. This kind of comparative study can be extended by observations of the abilities of different cells to utilize possible precursors instead of the recognized growth factors. The work of Bonner and Buchman (1938), using isolated pea roots to study the biosynthesis of the thiazole moiety of aneurin, is a good example of this.

\section{Anti-metabolites}

The use of growth inhibitors modelled on the structures of known essential metabolites gives a direct approach for investigating the routes of biosynthesis of these substances. Already a sufficiently large number of anti-metabolites inhibiting growth has been prepared to show the value of this mode of approach. As is known, this work received a new impulse when Woods (1940) found that $p$-aminobenzoic acid was a naturally occurring and very specific antagonist of the growth inhibition exercised by sulphanilamide. The conclusion which was drawn that $p$-aminobenzoic acid would prove to be an essential metabolite was soon substantiated; several species of micro-organisms are now known for which $p$-aminobenzoic acid is an. essential growth factor. The generalization about the modelling of growth inhibitors on the structure of essential vor. 4,1946 ] 
metabolites was put forward by Fildes (1940). The high structural specificity of the essential metabolites themselves forms the framework for this kind of study, and is part of the evidence supporting the conception of common and fundamental reactions in cell metabolism with which these anti-metabolite growth inhibitors interfere. This work is now being developed so rapidly that only a few examples can be given here.

Inhibitors of $\mathbf{p}$-Aminobenzoic Acid

Figure 1 shows some growth inhibitors modelled on the structure of $p$-aminobenzoic acid, and which are antagonized by it. It is not possible
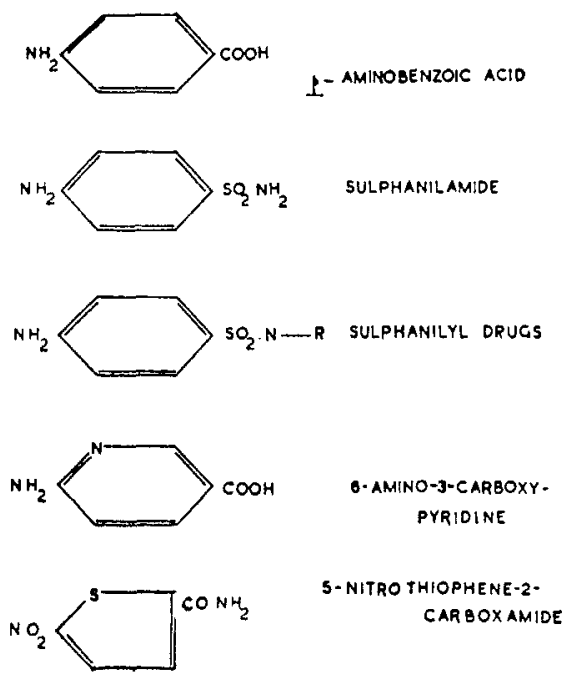

Figure 1. Some Growth Inhibitors Having Structures Modelled on that of $p$-AminobenzolC ACID AND INHIBITED BY IT.

here to give details of the numerous other compounds used which bear on the specificity of the $p$-aminobenzoic acid structure as regards both metabolites and anti-metabolites, and on the abilities of different microorganisms to utilize or detoxicate some closely related derivatives. In general, to be inhibitors, all anti-metabolites have to be sufficiently like the metabolite in shape, size, dissociation constants and so forth, and yet to be sufficiently different to be non-utilizable (Woods, 1940; Johnson, Green and Pauli, 1944).

\section{Inhibitors of Nicotinic Acid}

For certain organisms McIlwain (1940) found that pyridine-3-sulphonic acid was more effective against growth promoted by the acid, and the sulphonamide against growth promoted by the amide. Woolley (1945) observed symptoms of nicotinic acid deficiency in mice given 3-acetylpyridine, but it was not an effective bacterial inhibitor (Figure 2). 


\section{Inhibitors of Pantothenic Acid}

Figure 3 shows a number of compounds related to pantothenic acid which are inhibitory to, and antagonized by, pantothenic acid (McIlwain,

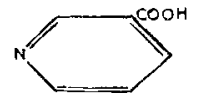

PYRIDINE -3-CARBOXYLIC ACIO NICOTINIC ACID

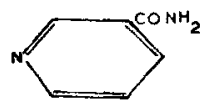

NICOTINAMIDE

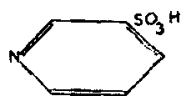

PrRIDINE-3-SULPHONIC ACIB
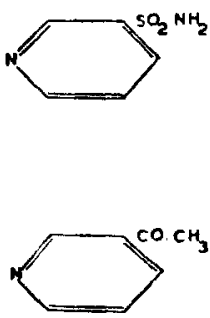

3-ACETYL PYRIDINE

Figure 2. Nicotinic Acid and some Inhibitors.

1942; Barnett, 1944; Madinaveitia, Martin, Rose and Swain, 1945; Pollack, 1943).

The respiration and growth of yeasts which were promoted by the presence of $\beta$-alanine were inhibited by presence of $\alpha$-methyl- $\beta$-alanine,

$$
\begin{aligned}
& \mathrm{CH}_{2} \mathrm{OH} \cdot \mathrm{C}_{\mathrm{I}_{3}}^{\mathrm{C} \mathrm{H}_{3}} \mathrm{CHOH} . \mathrm{O} . \mathrm{NH} \cdot \mathrm{CH}_{2} \mathrm{CH}_{2} \mathrm{COOH} \\
& \text { PANT-NH } 2 \mathrm{CH}_{2} \mathrm{CH}_{3} \mathrm{COOH} \\
& \text { PANTOTHENIC ACID } \\
& \mathrm{CH}_{2} \mathrm{OHC} \mathrm{CH}_{3}^{\mathrm{CH}_{3}} \mathrm{CHOH} \text {. C. NH.CH } \mathrm{CH}_{2} \mathrm{CH}_{2} \mathrm{SO}_{3} \mathrm{H}^{\mathrm{O}} \\
& \text { B-ALANINE } \\
& \mathrm{NH}_{2} \mathrm{CH}_{2} \mathrm{CH}_{2} \mathrm{COOH}
\end{aligned}
$$

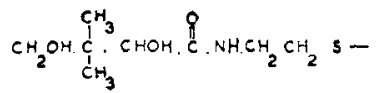

$$
\begin{aligned}
& \mathrm{NH}_{2} \mathrm{CH}_{2} \prod_{\mathrm{CH}_{3}}^{\mathrm{CH} \mathrm{COOH}} \\
& \text { ISO-SERINE } \\
& \mathrm{NH}_{2} \mathrm{CH}_{2} \mathrm{CH} \mathrm{COOH}_{\mathrm{OH}} \\
& \mathrm{CH}_{2} \mathrm{OH}_{\mathrm{CH}_{3}}^{\mathrm{CH}_{3}} \mathrm{CHOH}_{3} \mathrm{O} \text { PANTOY NH NHOPAZIDE } \\
& \text { 3-AMINOQUTRYIC ACIO }
\end{aligned}
$$

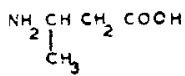

Figure 3. Compoundos Regated to Pantoterentc ACID WHICH ARE INHIBITORY TO, AND ANTAGONIZED BY, IT.

iso-serine and $\beta$-aminobutyric acid (Hartelius, 1943; Nielsen and Johansen, 1943). The effects were annulled by addition of $\beta$-alanine, and no voL. 4, 1946] 
inhibitory effect was exercised when pantothenate was used to promote growth. It seems probable that these substances were interfering with the use of $\beta$-alanine in the biosynthesis of pantothenic acid.

\section{Inhibitors of Riboflavin}

Numerous compounds related in structure to riboflavin, have been found more or less specifically inhibitory, and to be antagonized by riboflavin (Figure 4). Iso-riboflavin produced symptoms of riboflavin

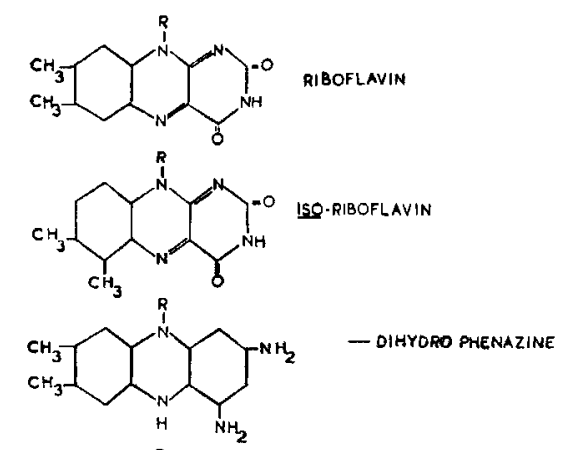

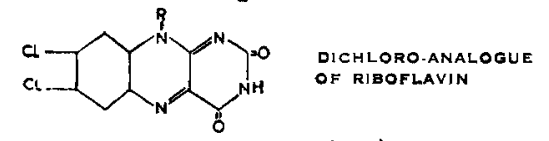

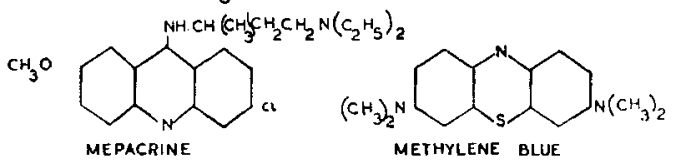

Figure 4. Compoundo Related in Structure to Rrbonlavin and ANtagonistic to it.

deficiency in rats (Emerson and Tishler, 1944). Certain phenazine analogues of riboflavin inhibited various bacteria and caused mild deficiency symptoms in mice, the effects again being antagonized by use of riboflavin (Woolley, 1944, 1, 2). Bacterial inhibition by mepacrine and methylene blue, which have a formal similarity of structure with riboflavin, was abolished by the presence of riboflavin, and so also was the inhibition caused by the other anti-malarial substances, quinine and propamidine, whereas the action of a number of other bactericidal substances was not abolished in the same conditions (Madinaveitia, 1944). The possible relation of riboflavin to the inhibition exercised by mepacrine and methylene blue is intriguing, but does not appear to bo so simple an effect as may exist in the case of other inhibitions of metabolites by anti-metabolites, especially since bacterial inhibitions by propamidine and mepacrine can be reversed by polyamines (Snell, 1944; Silverman and Evans, 1944), and inhibitions due to quinine have been related to co-zymase by Johnson and Lewin (1945). In the last case there was evidence that quinine formed a loose complex with the protein of the enzyme system. The dichloro-analogue of riboflavin provided another 
way of altering the riboflavin molecule to produce an inhibitor reversible by riboflavin (Kuhn, Weygand and Möller, 1943).

\section{Inhibitors of Aneurin}

Administration of pyrithiamin produced symptoms of aneurin deficiency in mice and inhibited the growth of micro-organisms which require intact aneurin for growth (Woolley and White, 1943, 1, 2) (Figure 5).

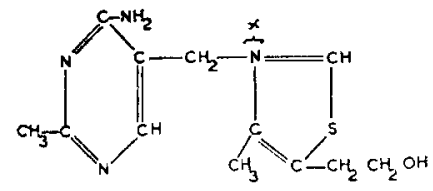

ANEURIN (THIAMAM)

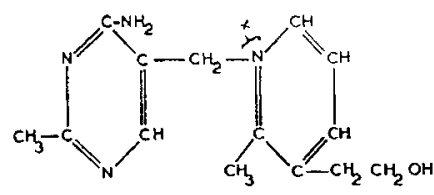

PYR!THIAMINI
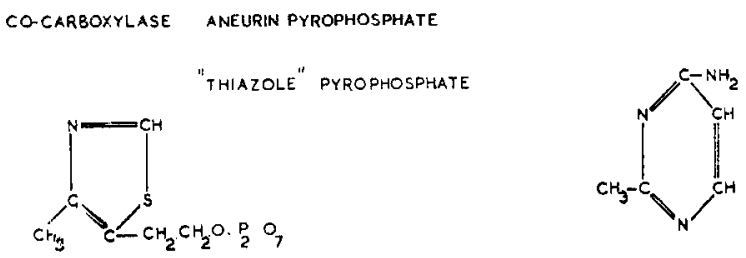

Figure 5. Aneurin, its Inhrbitor, Pyrithiamin, and Related Compounds.

It inhibited also almost as effectively those micro-organisms which require only the pyrimidine moiety of aneurin as a nutrient, but was less effective against those organisms which require both the thiazole and pyrimidine constituents of aneurin together, and was almost without effect on those organisms which synthesize aneurin. In the last case, however, it was concluded that the resistance to pyrithiamin was not due to the synthesis of amounts of aneurin large enough to antagonize the inhibitor. A deliberately developed strain of Endomyces vernalis, resistant to pyrithiamin, still required aneurin or its pyrimidine moiety for growth, and was apparently better equipped than the normal strain to destroy pyrithiamin, but even this did not entirely account for the ability of the resistant strain to protect itself against the inhibitor (Woolley, $1944,3)$.

The inhibition of carboxylase activity by the presence of the pyrophosphate of the thiazole moiety of aneurin is an interesting example of the voL. 4, 1946] 
use of an intermediate structure in studying the physiological role of a vitamin (Buchman, Heegard and Bonner, 1940). The results suggest a competition between co-carboxylase (aneurin pyrophosphate) and the "thiazole" pyrophosphate for the specific carboxylase protein, the thiazole pyrophosphate making the corresponding inactive "enzyme analogue". The obsorvations of Sarett and Cheldelin (1944) on the relations between the inhibition of growth of certain micro-organisms by pyrithiamin, and their utilization of aneurin, monophospho-aneurin and diphospho-aneurin show the use of an anti-metabolite inhibitor to study the utilization of a growth factor. Lactobacillus fermenti requires the intact aneurin molecule for growth, and diphospho-aneurin (cocarboxylase) is about 30 per cent. more active. It is usually assumed that those organisms which require the whole or part of the aneurin molecule use it, at least in part, to make co-carboxylase. It was found that pyrithiamin and some 6-aminopyrimidines inhibited the utilization of diphospho-aneurin by L. fermenti, more than they inhibited the utilization of aneurin. The results were interpreted as indicating that the carboxylase formed from aneurin is a more firmly bound enzyme than that formed when diphospho-aneurin is used as growth factor, and as suggesting that aneurin is attached to the apo-enzyme before phosphorylation for normal growth requiring aneurin as a growth factor.

\section{Inhibitors of Biotin}

Examination of degradation products of biotin has shown that certain yeasts could utilize some of them to a greater or less extent, while Lactobacillus casei required the complete biotin molecule (Figure 6). For a yeast strain examined the following comparative activities expressed as percentages were found: biotin 100, desthiobiotin 100, di-amino-acid obtained by opening the urea ring 10 , and di-aminopelargonic acid 10 (Dittmer and du Vigneaud, 1944). The suggestion is that this yeast could use these degradation products for the synthesis of biotin which was the active metabolite really required. Possibly the utilization of pimelic acid as a growth factor by certain strains of $C$. diphtheriae is an example of a still earlier stage in the biosynthesis of biotin (Mueller, 1937). Pimelic acid, suberic acid and azelaic acid all increased the synthesis of biotin by Aspergillus niger, while the homologous dicarboxylic acids below pimelic acid did not (Eakin and Eakin, 1942).

Inhibitors modelled on biotin have been prepared. Biotin sulphone was very active in inhibiting $L$. casei, L. arabinosus and Staph. aureus, but it was able to some extent to replace biotin as a growth stimulant for a yeast, being 0.1 per cent, as effective as biotin at a concentration equivalent to the maximum effect of biotin (Dittmer and du Vigneaud, 1944). Imidazolidone derivatives (Dittmer and du Vigneaud, 1944), and ureylene-benzene and ureylene-cyclohexane derivatives (English, Clapp, Cole, Halverstadt, Lampen and Roblin, 1945), modelled on the biotin structure, inhibited $L$. casei, the inhibition being reversed in presence of biotin. The most active imidazolidone derivatives were those where the fatty acid side chain was $-\left(\mathrm{CH}_{2}\right)_{5} \mathrm{COOH}$, i.e., corresponding to pimelic acid, if this were incorporated in the biotin structure (Dittmer and du Vigneaud, 1944). With the ureylene-benzene and ureylene-cyclohexane inhibitors the effectiveness was greatest with the cyclohexane 
derivatives. With $L$. casei the position of the side chain with respect to the ureylene ring seemed less important than the length of the chain; with yeast the position of the side chain was more important than its length. When the side chain was decreased to a simple carboxyl group the inhibition was negligible.

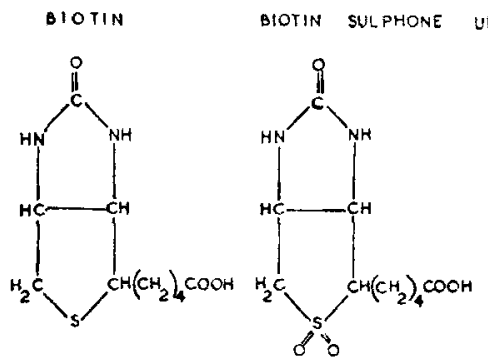

UREYLENE-DENZENE DERIV.UREYLENE CYCLOHEXANE - OERIV.

OESTHIOBIOTIN

DIAMINO CAR BOXYLIC ACIO FROM BIOTIN
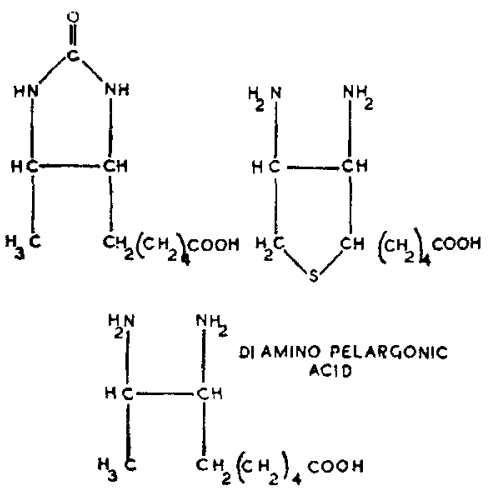
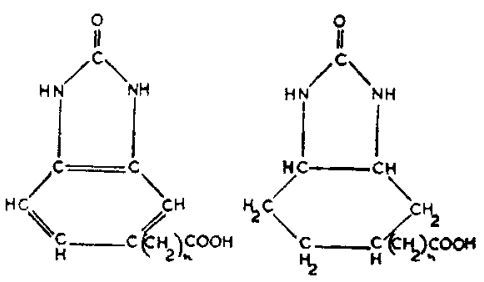

4-(IMIDAZOLIDONE-2) ACIOS

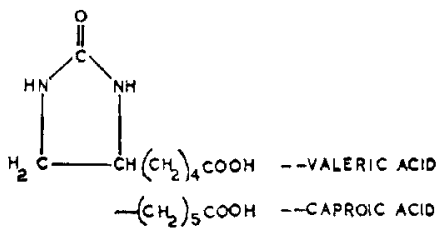

PIMElic ACID<smiles>O=C(O)CCCCCCC(=O)O</smiles>

Figure 6. Biotin, its Degradaton Products and Inhibitors.

\section{Inhibitors of Purines}

Various purines and pyrimidines found in nucleic acids are essential growth factors or growth stimulants for different species of microorganisms; in some cases these effects are related to the need for other growth factors. Thus, micro-organisms show examples of deficiency in purine and pyrimidine synthesis. Inhibitors modelled as direct purine antagonists have been prepared (Figure 7); these were tri-azolopyrimidines corresponding to adenine, hypoxanthine, guanine and xanthine (Roblin, Lampen, English, Cole and Vaughan, 1945). Inhibition of growth of Bact. coli and Staph. aureus was effectively antagonized only by the most closely related purines. Benzimidazole inhibited certain yeasts and bacteria, the inhibition being annulled by the corresponding adenine and guanine (Woolley, 1944, 1). 


\section{Inhibition in General}

In some instances the anti-metabolites inhibit best those organisms which do not synthesize the corresponding metabolite and which, therefore, require it as a growth factor. In these cases it is possible that the inhibitor acts by competition in an enzyme system which would normally
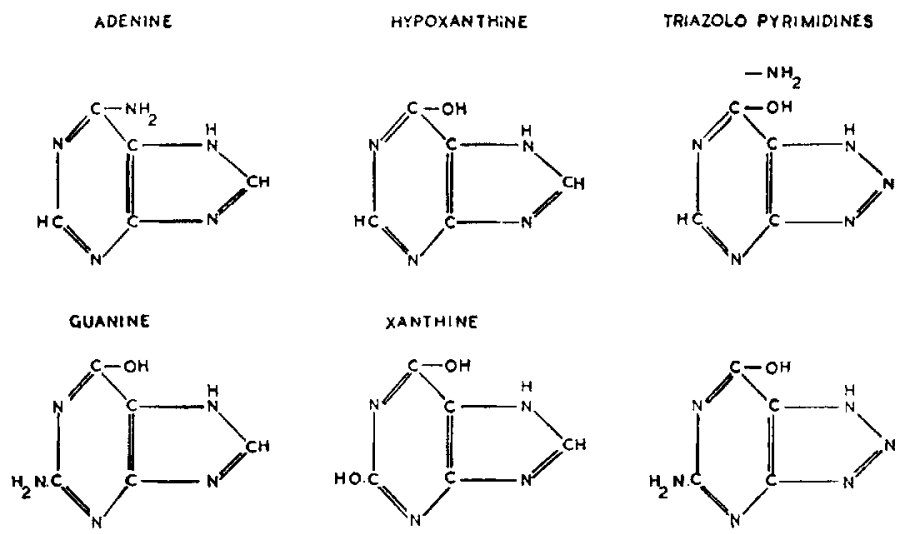

BENZIMIDAZOLE

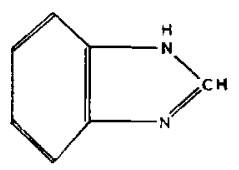

Figure 7. Inhibition of Purinims.

utilize the metabolite for some higher stage of biosynthesis, but this is not always the case. The sulphanilyl inhibitors inhibit also organisms which synthesize $p$-aminobenzoic acid, and benzimidazole inhibits organisms which synthesize adenine and guanine. It may be that these differences are related to the amounts of the metabolite which the synthesizing organisms can make. Some strains resistant to inhibitors are apparently resistant because they have become able to produce abnormally large amounts of the metabolite (Landy, Larkum, Oswald and Streightoff, 1943), but this again, as in the case of resistance to pyrithiamin (Woolley, 1944, 3), is not always the explanation of resistance. The effectiveness of an inhibitor may be related to its capacity for interfering with the actual steps in a chain of synthetic reactions. Observations of this kind raise a whole series of questions relating to the mode of action of the inhibitors, on the one hand, and to the routes of biosynthesis or utilization of growth factors on the other.

\section{Inter-relations of Metabolites and Anti-metabolites}

The intricacies of the relations between different chains of metabolic reactions are well illustrated in this field of metabolite and anti-metabolite 
studies, and emphasize the need to consider cell metabolism as a whole. Thus, Harris and Kohn (1941) showed that $l(-)$ methionine was a relatively spocific antagonist of the inhibition of the growth of Bact. coli caused by sulphanilyl compounds although less effective than $p$ aminobenzoic acid. They suggested that methionine was effective as an antagonist of the sulphanilyl compounds because these acted primarily by inhibiting the synthesis of methionine, and that it was this synthesis which was dependent on the presence of $p$-aminobenzoic acid. Their extremely interesting finding that methionine could be made an essential growth factor for a strain of Bact. coli by cultivation in the presence of methionine and sulphanilamide supports their conception of the inter. relation of methionine and $p$-aminobenzoic acid in metabolism (Kohn and Harris, 1942).

Snell and Guirard (1943) found that alanine in sufficient concentration could completely replace pyridoxin for the growth of Streptococcus lactis; no other amino-acid did this. In the conditions of the test, glycine and threonine and, at higher concentrations, serine and $\beta$-alanine inhibited growth. This inhibition was abolished by pyridoxin but by no other vitamin, and by alanine. Examples of inhibitions by certain amino-acids and their antagonization by other amino-acids, at very low concentrations, were first carefully studied by Gladstone (1939) but, in the case studied by Snell and Guirard (1943), there is the further relation with pyridoxin metabolism. Thus both the examples mentioned here are cases where, presumably, metabolic reactions involving the essential metabolites, $p$-aminobenzoic acid and pyridoxin, are linked with reactions involving amino-acids. It is clear that the further study of these and similar interrelationships between metabolites and anti-metabolites, in which use is made of possible intermediates or precursors and corresponding inhibitors modelled on their structures, can be a valuable technique for investigating routes of biosynthesis.

In conclusion it may be said that the stage of discovering essential metabolites by characterizing growth factors is now passing to a higher stage. More growth factors will be found, but in a sense this is becoming a routine search. Emphasis can now be placed on the purposeful study of the physiological functions of the essential metabolites. It seems probable that the use of inhibitors modelled on the structures or partial structures of essential metabolites will be a valuable tool for investigating the biogenesis of the functioning mechanisms of cell metabolism.

\section{REFERENCES}

Barnett, J. (1944). J. chem. Soc. p. 5.

Bonner, J, and Buchman, E. R. (1938). Proc. nat. Acad. Sci., Wash., 24, 431. Buchman, E. R., Heegard, E. and Bonner, J. (1940). Proc. nat. Acad. Sci., Wash., 26, 561 .

Dittmer, K. and du Vigneaud, V. (1944). Science, 100, 129.

Eakin, R. E, and Eakin, E. A. (1942). Science, 96, 187.

Emerson, G. A. and Tishler, M. (1944). Proc. Soc. exp. Biol., N.Y., 55, 184.

English, J. P., Clapp, R. C., Cole, Q. P., Halverstadt, I. F., Lampen, J. O. and Roblin, R. O. (Jr.) (1945). J. Amer. chem. Soc. 67, 295.

Fildes, P. (1940). Lancet, 238, 955 .

Gladstone, G. P. (1939). Brit. J. exp. Path. 20, 189.

Harris, J. S. and Kohn, H. I. (I941). J. Pharmacol. 73, 383.

Harris, L. J. and Kodicek, E. (1946). Proc. Nutr. Soc. 4, 81.

Hartelius, V. (1943). Naturwissenschaften, 31, 440.

vor. 4,1946$]$ 
Johnson, F. H., Green, D. E. and Pauli, R. (1944). J. biol. Chem. 153, 37.

Johnson, F. H. and Lewin, I. (1945). Science, 101, 281.

Kohn, H. I. and Harris, J. S. (1942). J. Bact. 44, 717.

Kuhn, R., Weygand, F. and Möller, E. F. (1943). Ber. dtsch. chem. Ges. 76, 1004.

Landy, M., Larkum, N. W., Oswald, E. J. and Streightoff, F. (1943). Science, 97, 265.

McПlwain, H. (1940). Brit. J. exp. Path. 21, 136.

Mellwain, H. (1942). Biochem. J. 36, 417.

Madinaveitia, J. (1944). Biochem. J.38, xxvii.

Madinaveitia, J., Martin, A. R., Rose, P. L. and Swain, G. (1945). Biochem. J. $39,85$.

Mueller, J. H. (1937). J. Bact. 34, 163.

Nielsen, N. and Johansen, G. (1943). Naturwissenschaften, 31, 235.

Pollack, M. A. (1943). J. Amer, chem. Soc. 65, 1335.

Quastel, J. H. (1946). Proc. Nutr. Soc. 4, 92.

Roblin, R. O., Jr., Lampen, J. O., English, J. P., Cole, Q. P. and Vaughan, J. R., Jr. (1945). J. Amer. chem. Soc. 67, 290.

Sarett, H. P. and Cheldelin, V. H. (1944). J. biol. Chem. 156, 91.

Silverman, M. and Evans, E. A. Jr. (1944). J. biol. Chem. 154, 521.

Snell, E. E. (1944). J. biol. Chem. 152, 475.

Snell, E. F. and Guirard, B. M. (1943). Proc. nat. Acad. Sci., Wash., 29, 66.

Stokes, J. L. (1944). J. Bact. 48, 201.

Woods, D. D. (1940). Brit. J. exp. Path. $21,74$.

Woolley, D. W. $(1944,1)$. J. biol. Chem. 152, 225.

Woolley, D. W. (1944, 2). J. biol. Chem. 154, 31.

Woolley, D. W. (1944, 3). Proc. Soc. exp. Biol., N.Y., 55, 179.

Woolley, D. W. (1945). J. biol. Chem. 157, 455.

Woolley, D. W. and White, A. G. C. $(1943,1)$. J. biol. Chem. 149, 285.

Woolley, D. W. and White, A. G. C. (1943, 2). J. exp. Med. 78, 489.

\section{Discussion}

Dr. F. Bergel (Roche Products, Ltd., Broadwater Road, Welwyn Garden City, Herts.), opener: It is proposed to touch only on ore point, namely, the specificity of chemical constitution and activity of the B group of vitamins, especially for mammals. I should like to draw attention to differences which exist in this respect between the major $B$ vitamins, vitamin $B_{1}$ and $B_{2}$ and nicotinic acid, and the minor ones such as pantothenic acid and pyridoxin, which might explain why only three vitamin $B$ deficiency diseases are so far known in man. This division into major and minor vitamins was first suggested by $R$. J. Williams (1942) and R. R. Williams (1942).

Vitamin $B_{1}$ is chemically highly specific. In a recent paper Buchman and Richardson (1945) showed that any change of the hydroxyethyl group in the thiazole ring went hand in hand with loss of activity. Bergel and Todd (1937) demonstrated several years ago that, in addition to this group, the 4-amino-group in the pyrimidine nucleus, and the 2-hydrogen in the thiazole, and the methylene group connecting the two rings, are essential.

A similar state of affairs is found with the $B_{2}$ vitamins. Karrer (1939) showed that even slight alterations in the molecular structure of riboflavin caused loss of vitamin activity. It seems that the 6:7-methyl groups, the ribityl side chain, and a free hydrogen in the alloxan part, are essential.

Even the simple molecule of nicotinic acid appears to possess specificity at least in the 3-carboxyl group and the nitrogen containing ring system. A second carboxyl group as in quinolinic acid and the change of the 